\title{
Characterization of the toxic effects of alcohol in the geriatric life style
}

\begin{abstract}
Background: alcohol consumption and its toxic consequences in elderly is an essential element in current healthcare work from the health professionals themselves. Objective: to characterize of the toxic effects of alcohol in the geriatric life style.

Methods: A descriptive, cross-sectional study was conducted in a health area, where from a population of 80 there was a sample of 41 elderly with alcohol consumption belonging to the "José Ramón León Acosta" polyclinic in Santa Clara. Empirical and statistical methods, open interview and review of individual medical records were used.

Results: The group predominated between 60 and 75 years (78\%). The male sex began to manifest addiction at younger ages with respect to the female sex $(p=0.031)$ The most common reason was group emotional contagion $(97,6 \%)$ and the presence of low tolerance to frustrations $(75,6 \%)$. The most frequent route of initiation was sociocultural (39\%) followed by those who use the hedonic route as a way of seeking pleasure among their peers $(24,4 \%)$. Both sexes behave similarly in terms of the reasons for alcohol consumption and the initiation pathway $(\mathrm{p}>0.05)$.
\end{abstract}

Conclusions: Alcohol consumption in elderly is a real health problem. Elderly initiate alcohol consumption. It is very important to carry out health actions to prevent this toxic substance.

Keywords: Elderly, alcoholism, life style, active aging, prevention, health
Volume 4 Issue 5 - 2018

\author{
Jesús Cuéllar Álvarez ,' Félix Arley Díaz \\ Rossel, ${ }^{2}$ Mirelys Olmo Quiñones ${ }^{3}$ \\ 'Department of Psychology, Central University Marta Abreu of \\ Las Villas, Cuba \\ ${ }^{2}$ Central University Marta Abreu of the Villas, Cuba \\ ${ }^{3}$ Department of Infirmary, Cuba
}

Correspondence: Jesús Cuéllar Álvarez, Department of Psychology, Central University Marta Abreu of Las Villas, Cuba, Email jesusca@infomed.sld.cu

Received: August 18, 2018 | Published: September 12, 2018

\section{Introduction}

The biggest adult in Cuba occupies more than 19\%, and it is expected that for the year 2025, one of each four Cubans is mature bigger. Of this population one percent is only in institutions, 9\% lives alone and the rest cohabits with family, with the result that Villa Clara is one of the most aged counties in Cuba. ${ }^{1}$ The active aging depends on a variety of influential or decisive factors that surround to the individuals, the families and the nations. These include material conditions as well as social factors that affect to the behavior types and individual feelings. ${ }^{2}$ The call third age, also well-known with the terms of age, bigger adulthood or elderly, it has been approached in the literature in an isolated way or I eat involution phase and I don't eat an authentic stage of the human development. It is located around the sixty years, associated to the event of the labor jubilation. ${ }^{3}$ Alcoholism is a disease caused by the abusive consumption of alcoholic beverages and by the addiction that this habit creates. The figures of adolescents and young consumers increase every year. ${ }^{4}$ Prevention is an important resource within society to prevent different evils from reaching or expanding. This term is defined as actions aimed at the eradication, elimination and minimization of the impact of the disease and disability; It includes social, political, economic and therapeutic measures. ${ }^{5}$

It is a reality: teenagers, parties and alcoholic beverages are related, it is not about absolutizing, but neither can one deny vulnerability, the risk to which they are exposed, and, therefore, the most significant efforts in the fight against toxic substances should be directed towards prevention. ${ }^{6}$ The World Health Organization cited by Vignolo et al., ${ }^{7}$ states that primary prevention strategies may be aimed at prohibiting or reducing the exposure of the individual to the harmful factor, up to levels not harmful to health. At present, there are insufficiencies in community care work to address the problem of alcohol consumption in elderly, which led to the present study aimed at solving the following scientific problem:

What are the characteristics of the toxic effects of alcohol in the geriatric life style from a health area belonging to the "José Ramón León Acosta de Santa Clara" polyclinic? The general objective is to characterize of the toxic effects of alcohol in the geriatric life style.

\section{Methods}

A descriptive, cross-sectional study was carried out in a health area, belonging to the "José Ramón León Acosta" polyclinic of Santa Clara municipality, in the period from July 2017 to July 2018.

80 elderly who consumed alcohol were studied, and the simple random sampling without replenishment probabilistic technique was used for the sample selection. It was constituted by 41 elderly, who were previously informed consent.

\section{Methods of the theoretical level}

Synthetic analytical: It made possible the interpretation of each one of the studied texts, to conform the criterion assumed in the epigraphs and paragraphs, as well as to particularize in the data obtained in the surveys to integrate them and to establish the corresponding generalizations. Inductive-deductive: It facilitated going from the particular to the general in each of the analyzes carried out in the theoretical study and in the processing of the obtained information. Generalization: It allowed the establishment of the regularities that were revealed in the study carried out. 


\section{Methods of the empiric level}

Open interview: Contributed to identify the toxic effects of the alcohol consumption in elderly Individual clinical histories: It made it possible to provide information on various personals.

\section{The selection criteria were the following \\ Inclusion approaches}

All elderly with previous consumption of alcoholic beverages That they reside in the health area belonging to a health area and are dispensed.

\section{Exclusion approaches}

Elderly whose legal guardians do not give consent to participate in the investigation.

The following variables were used from the data obtained: age, sex and toxic effects of alcohol consumption

\section{Collection of information}

In order to carry out the research, the documentary review and individual clinical histories were used as techniques in order to obtain extended information.

\section{Statistic analysis}

The information was stored in a data file in SPSS version 21.0 and is presented in tables and statistical graphs, for the description the arithmetic mean, standard deviation, absolute frequencies and percents were calculated. In the analysis we used a comparison test of two proportions and a comparison of means for independent samples through Epidat 4.2. We worked with levels of significance of $5 \%$.

\section{Process}

To begin the development of the research, a bibliographic review was made with the use of the database by Pubmed of the subject with a thorough analysis of the most relevant aspects in the Cuban environment as well as at an international level.

\section{Results}

As can be seen in Table 1 referring to age of onset in alcohol consumption and sex, the group predominated between 60 and 75 years $(78 \%)$. Table 2 refers to the toxic effects of alcohol consumption according to sex, where it was appreciated that the most common effects of alcohol consumption was the desire to die $(97,6 \%)$, followed by the presence of low tolerance to frustrations $(75,6 \%)$ and low self-esteem with $70,7 \%$.

Table I Distribution of elderly according to age in alcohol consumption

\begin{tabular}{llllllll}
\hline $\begin{array}{l}\text { Age of } \\
\text { alcohol } \\
\text { consumption }\end{array}$ & \multicolumn{2}{l}{ Fex } & & & & \\
\cline { 2 - 7 } & No. & $\%$ & No. & $\%$ & No. & $\%$ \\
\cline { 2 - 7 } & 8 & 66,7 & 24 & 82,8 & 32 & 78,0 \\
$70-75$ & 4 & 33,3 & 5 & 17,2 & 9 & 22,0 \\
Total & 12 & 100,0 & 29 & 100,0 & $4 \mid$ & 100,0 \\
Media \pm DE & $15,2 \pm 1,8$ & $13,8 \pm 1,6$ & $14,2 \pm 1,7$ \\
\hline
\end{tabular}

Source: Epidat Database
Table 2 Distribution of elderly according to toxic effects of alcohol consumption and sex

\begin{tabular}{|c|c|c|c|c|c|c|c|}
\hline \multirow{3}{*}{$\begin{array}{l}\text { Effects of } \\
\text { alcohol } \\
\text { consumption }\end{array}$} & \multicolumn{6}{|l|}{ Sex } & \multirow{3}{*}{$\begin{array}{l}\text { Z } \\
\text { Value -p }\end{array}$} \\
\hline & \multicolumn{2}{|c|}{ Female } & \multicolumn{2}{|c|}{ Male } & \multicolumn{2}{|c|}{ Total } & \\
\hline & No. & $\%$ & No. & $\%$ & No. & $\%$ & \\
\hline Desire to die & II & 91,6 & 29 & 100,0 & 40 & 97,6 & $\begin{array}{l}Z=0,464 \\
p=0,645\end{array}$ \\
\hline $\begin{array}{l}\text { Low tolerance } \\
\text { for frustrations }\end{array}$ & 9 & 75,0 & 22 & 75,9 & 31 & 75,6 & $\begin{array}{l}Z=0,341 \\
p=0,733\end{array}$ \\
\hline Low self-esteem & 8 & 66,7 & 21 & 72,4 & 29 & 70,7 & $\begin{array}{l}Z=0,009 \\
p=0,993\end{array}$ \\
\hline $\begin{array}{l}\text { Situational } \\
\text { depression }\end{array}$ & 8 & 66,7 & 20 & 68,7 & 28 & 68,3 & $\begin{array}{l}Z=0,225 \\
p=0,822\end{array}$ \\
\hline $\begin{array}{l}\text { Physical } \\
\text { deterioration }\end{array}$ & 5 & $4 I, 7$ & 14 & 48,3 & 19 & 46,3 & $\begin{array}{l}Z=0,042 \\
p=0,966\end{array}$ \\
\hline Anxiety & - & - & 3 & 7,3 & 3 & 7,3 & $\begin{array}{l}Z=0,498 \\
p=0,618\end{array}$ \\
\hline
\end{tabular}

\section{Source: Epidat Database}

It is important to highlight that elderly who feel depressed have a high probability of consuming alcohol as aversive way, ${ }^{12}$ which was reflected in the present work, where $68,3 \%$ of the subjects admitted that they had done it for causes of situational depression.

When analyzing the percentage of elderly for each of the reasons by sex, no statistically significant differences were found according to the results of the comparison test of two proportions for independent samples $(\mathrm{p}>0.05)$

\section{Discussion}

In Cuba, a study conducted in Havana during 2012 found a higher percentage of alcoholics than what was suggested by the analysis of the health situation. ${ }^{8}$ The results of the present investigation reflect this reality. While Cuban elderly reported relatively low alcohol consumption, most began drinking before age 60 and frequently answered that they did so for fun or to relieve stress and feel relaxed influenced by a group contagion. From the results it was evident that the incidence of alcoholism tends to increase in Cuba because from very early ages and through dissimilar routes: social or cultural, the reality is that the trend increases both on weekdays and weekends, to which contributes the sale of beer and alcoholic beverages in free areas; The same happens with respect to the tolerance of consumption in parks and squares on holidays or weekends, despite the existing regulations. ${ }^{9}$ In the revised bibliography ${ }^{10}$ it was found that those who are more likely to have alcoholism are those elderly exposed to the sociocultural pathway, among which is the consumption of alcohol in the male sex. This approach corresponds to the results obtained in the interviews conducted with the group where they said they drink when they go out for a walk, at parties and sharing tastes and preferences with friends. The effects derived from the consumption of alcohol are not only an individual problem, but also a community one. ${ }^{11}$

The results of this investigation belong together since with the world and national tendency every time it increases more the habit in the biggest adults. It coincides with a study carried out by Ariza C, Nebot M, Díez AND, Tomás Z, Valmayor S. ${ }^{12}$ about the alcoholism in adults in a community in Spain, where it was reported that the half age of beginning in this habit, is located among the 60 years of age. 
Other studies ${ }^{13}$ outline that the early beginning of the habit of smoking brings future problems of health and it is the entrance door for the consumption of alcohol or other legal drugs. Previous research reveals the family consequences caused by alcoholism and the presence of rejection of these patients in families with an alcoholic member, which coincides with this investigation. In studies carried out by Sandoval Ferrer, feelings of extreme intolerance predominate, rejection of the alcoholic, guilt and shame among family members, especially on the part of the children and grandchildren; these results agree, in terms of family refusal, with those of this work. ${ }^{14}$

The group of friends appears as the main starting point in consumption, if reference is made to the literature, these elderly people started in the practice of consumption through the socio-cultural way, based on customs, shared norms and the pressure of the group given the influence on the subject, result obtained in Correspondence with research found. ${ }^{15}$ Although the risk is defined as an action that may involve a loss, each subject understands it according to their own perceptions; reason why the authors of this article call for reflection all those involved in the elderly attendance, including family, schools and community factors.

The situation described in the Cuban and Mexican contexts is not unique. For example, a Colombian study found that $85 \%$ of elderly people between the ages of 60 and 75 had consumed alcohol at some point in their lives. A similar percentage $(80,4 \%)$ had done so in the previous year and approximately half of the elderly people studied in the previous month. ${ }^{16}$ Based on the results of this research, we worked to fulfill the main objective, which was to characterize the toxic effects of alcohol on the lifestyle of the elderly and to provide integral health care aimed at preventing this social scourge.

\section{Conclusions}

Alcohol consumption in elderly is a real health problem. The most common motive is group contagion and low tolerance to frustrations. It is very important to carry out health actions to prevent the toxic consequences caused by alcohol. The elderly in the study must adopt a new lifestyle as a determinant of health and modify inappropriate behaviors using a cognitive learning infrastructure for the benefit of their health. By way of conclusion, the dependence and tolerance associated with alcohol consumption in the elderly, cause's damage to their health causing biographical, social, psychological and spiritual deterioration that leads to going through various diseases. It is necessary according to the author of the research to carry out an educational and assistance action strategy to consciously improve the inadequate lifestyle of the elderly due to the excessive and harmful consumption of alcohol for health.

\section{Acknowledgements}

None.

\section{Conflict of interest}

The author declares no conflict of interest.

\section{References}

1. http://files.sld.cu/gericuba/files/2018/01/Tabaquismo.pdf

2. Collazo Ramos MI, Calero Ricardo JL, Rodríguez Cabrera AL. Necesidades, realidades y posibilidades del sistema de salud cubano para su enfrentamiento al envejecimiento poblacional. Rev Cubana Salud Pública. 2010;36(2).

3. https://studyres.es/doc/3457371/versi\%C3\%B3n-para-imprimir--convenci\%C3\%B3n-internacional-virtual-deCiencias Morfológicas.

4. Rodríguez Fernández MC, Cruz Rodríguez J. La necesaria relación intersectorial educación-salud en la lucha contra las drogodependencias. EDUMECENTRO. 2015;7(4):4.

5. Vignolo J, Vacarezza M, Álvarez C, et al. Niveles de atención, de prevención y atención primaria de la salud. Arch Med Int. 2011;33(1):8.

6. Brito G, Iraizoz AM, Alburquerque F. Pesquisa de alcoholismo y análisis bioético del daño que representa en una población cubana. Rev Cub Med Gen Integr. 2011;27(3):355-370.

7. http://legislacion.sld.cu/.

8. Chang de la Rosa M. El consumo de alcohol como un problema de salud pública. Rev Cub Hig Epidemiol. 2012;50(3):3.

9. Machado Barbery F, Calá García EJ. Caracterización del entorno social comunitario como extensión universitaria en ciencias médicas. EDUMECENTRO. 2014;6(2):9.

10. Pupo Ávila NL, Hechavarría Toledo S. La promoción de salud en el plan de estudio de la carrera de Medicina en Cuba. Educ Med Super. 2012;26(4):11.

11. Véliz Gutiérrez JA, Pérez Díaz N, Fernández Montequín Z, et al. La Extensión Universitaria y la Promoción de Salud en la Atención Primaria. Rev Ciencias Médicas de Pinar del Río. 2011;15(4):10.

12. Ariza C, Nebot M, Villalbí JR, et al. Tendencias en el consumo de tabaco, alcohol y cannabis de los escolares de Barcelona. Gac Sanit. 2012;17(3):190.

13. Larmusch SY. Adolescencia y drogadicción. Un enfoque de la prevención escolar en Argentina. 2014.

14. Sandoval Ferrer JE, Díaz Lóbregas JA, Velázquez Julián JL, et al. Caracterización de un grupo de familias con integrantes alcohólicos masculinos residentes en Cayo Hueso. Rev Hosp Psiquiátr La Habana. 2013;10(1):6.

15.http://www.revespcardiol.org/cgi-bin/wdbcgi.exe/cardio/mrevista_cardio. go?pident $=13047009$.

16. Arrieta KM. Consumo patológico de alcohol entre los estudiantes de la Universidad de Cartagena. Rev Salud Pública. 2009; 11(6):878-886. 